\title{
THE USE OF LITERATURE IN DEVELOPING STUDENTS' CHARACTERS THROUGH AUTHENTIC ASSESSMENT
}

Fadhillah Wiandari

IAIN Langsa

fwiandari@iainlangsa.ac.id

Siti Habsari

IAIN Langsa

sihabpratiwi@iainlangsa.ac.id

\section{Abstract}

Students' character can be developed in the learning process. Literature at schools in Indonesia is always considered complimentary and unimportant, even though literature is very influential in developing students' skill in language. Literature is an important source that can influence the development of students' character. This paper argues that the authentic assessment of the literary sources being taughtat schools helpsteachers to deal with ways of developingstudents' character. Thus, this paper is to demonstrate the authentic assessment of literary sources taught atthe third grade of elementary schools at MIN 2 Aceh Tamiang in developing students' character. The study used a mixed method; the use of experimental and qualitative methods. Experimental method was used to assess cognitive domains while qualitative descriptive was used to show affective and psychomotor domains. The findings show that in the cognitive domain, the assessment of poetry and drama are best carried through written, oral, and assignment tests. The affective domain is best performed through observation and journals while the psychomotor domain is done effectively through portfolios and performance appraisals. The paper shows that the literature teaching through authentic assessment at schools develops students' responsibility, hard work, creativity, friendliness, and discipline. The finding also reveals that the scores obtained by students have reached the minimum scores of passing after the use of authentic assessment.

\section{Keywords}

Penilaian autentik, Sastra, Pendidikan Karakter 


\section{LATAR BELAKANG}

Kondisi masyarakat saat ini sangatlah memprihatinkan. Permasalahan sering terjadi di mana-mana, seperti perkelahian, tawuran antar pdelajar, kecemburuan sosial, ketidakadilan, perampokan, korupsi, pelecehan seksual, penipuan, bahkan fitnah yang merajalela. Maraknya berbagai sikap hidup yang buruk ini telah ikut melemahkan karakter anak-anak bangsa dan telah mengubah mindset anak cenderung menjadi egois, baik terhadap dirinya sendiri maupun sesamanya. Mereka tidak lagi memiliki kepekaan terhadap sesama, kehilangan nilai kasih sayang, dan sibuk dengan dunianya sendiri yang cenderung agresif.

Indonesia sebagai bangsa yang beradab dan berbudaya, dengan adanya situasi seperti itu sangat tidak menguntungkan bagi masa depan bangsa, khususnya dalam melahirkan generasi masa depan yang cerdas, baik secara intelektual, emosional, spiritual, maupun sosial. Dalam konteks demikian, perlu ada upaya yang serius dari segenap komponen bangsa untuk membangun kesadaran bagi anak-anak demi mengembalikan karakter bangsa yang hilang. Dengan demikian, akan sangat menarik jika seorang pendidik bahasa dan sastra mampu memberikan nilai-nilai berwawasan pendidikan karakter ke dalam proses pembelajaran terutama pembelajaran sastra.

Ketika dunia pendidikan dinilai hanya mementingkan ranah pengetahuan semata, dan belum menerapkan ranah sikap dan keterampilan, maka perlu ada pembaharuan yang mampu mengajak dan menginternalisasikan penilaian autentik dan pendidikan karakter sesuai dengan tuntutan dan dinamika perkembangan psikososial anak pada saat ini.

Pendidikan karakter menurut Khan (2010) adalah proses kegiatan yang dilakukan dengan segala upaya yang dilakukan secara sadar dan 
terencana untuk mengarahkan peserta didiknya. Dengan adanya pendidikan karakter, diharapkan mampu mengubah kesadaran dan mindset anak menjadi lebih baik.

Di dunia pendidikan khususnya sekolah atau madrasah, pembelajaran sastra sangat diperlukan bagi siswa. Materi sastra diajarkan pada tingkat pendidikan dasar dengan tujuan membekali siswa menjadi insan yang halus budi dan insan yang memahami nilai estetika kehidupan. Salah satu materi pelajaran sastra di sekolah dasar adalah puisi dan dongeng. Oleh karena itu, seorang guru bahasa dan sastra mencoba memadukan antara pembelajaran puisi dan dongeng dan menilainya dengan menggunakan penilaian autentik berbasis pendidikan karakter.

Dengan puisi dan dongeng, anak-anak sejak dini dapat melakukan olah rasa, olah batin, dan olah budi secara intens sehingga secara tidak langsung anak-anak memiliki sikap atau perilaku dan kebiasaan positif melalui proses apresiasi dan berkreasi melalui karya sastra. Apalagi dengan ditambah adanya penerapan penilaian autentik yang harus dilaksanakan untuk menilai sejauh mana hasil yang didapat oleh siswa. Dengan adanya penilaian autentik, guru dengan mudah mengetahui bagaimana perkembangan sikap, perilaku, dan pengetahuan, bahkan skill peserta didik.

Menurut Sa'ud (2013) penilaian autentik adalah proses yang dilakukan guru untuk mengumpulkan informasi tentang perkembangan belajar yang dilakukan siswa. Penilaian autentik merupakan penilaian yang sangat penting dan diperlukan oleh guru. Dalam penilaian ini siswa tidak hanya dinilai pengetahuannya saja, tetapi siswa juga dinilai keterampilan dan sikap dalam setiap proses pembelajaran. 
Melalui penelitian ini penulis ingin menunjukan bahwa pembelajaran sastra khususnya puisi dan dongen dapat digunakan sebagai alat penyampaian pendidikan karakter kepada peserta didik dan dapat dinilai dengan penilaian autentik. Oleh karena itu, sangatlah penting untuk dapat diketahui tentang sejauhmana "Penilaian Autentik Pada Pembelajaran Sastra Berbasis Pendidikan Karakter".

\section{KAJIAN PUSTAKA}

\section{Pengertian Penilaian Autentik dan Ruang Lingkupnya}

Penilaian autentik (authentic assesment) adalah suatu proses pengumpulan, pelaporan dan penggunaan informasi tentang hasil belajar siswa dengan menerapkan prinsip-prinsip penilaian, pelaksanaan berkelanjutan, bukti-bukti autentik, akurat, dan konsisten sebagai akuntabilitas publik (Pusat Kurikulum, 2009).

Atmazaki (2013) menyatakan bahwa penilaian otentik adalah proses evaluasi yang menggunakan berbagai bentuk pengukuran kinerja yang merefleksikan prestasi belajar, motivasi, dan perilaku siswa dalam kegiatan belajar. Penilaian autentik ini dilaksanakan pada saat proses pembelajaran berlangsung hingga selesainya pembelajaran. Siswa tidak hanya dinilai pengetahuannya saja namun juga kinerjanya.

Adapun penilaian autentik yang dilaksanakan dalam pembelajaran sastra ini adalah penilaian observasi, kinerja, tes tulis, tes lisan, dan penugasan. Berikut penjelasan dari setiap penilaian:

a). Penilaian Observasi

Penilaian observasi adalah penilaian yang dilakukan pada setiap saat. 
Menurut Atmazaki (2013) penilaian observasi merupakan salah satu teknik penilaian alternatif yang dilakukan guru untuk mengetahui perkembangan berbahasa siswa. Muller (2004) menjelaskan bahwa setiap respon dan pertanyaan siswa menjadi perhatian guru, dicatat dalam lembar observasi untuk digunakan sebagai dasar memberikan komentar, perbaikan, dan penilaian. Sikap dan perilaku siswa tersebut dapat diamati secara langsung oleh guru.

b). Penilaian kinerja

Menurut Brown (2004) penilaian kinerja adalah penilaian yang menuntut siswa untuk menampilkan suatu tindakan berdasarkan pengetahuannya. Menurut Muller (2001) kinerja tersebut dapat berupa penelitian dan menulis laporan, menganalisis karakter tokoh cerita, menciptakan informasi penting berdasarkan bacaan, mendramatisasi cerita, dan lain-lain. Dengan demikian, tugas yang dikerjakan siswa menjadi lebih bermakna dan siswa dengan mudah memahami materi pembelajaran.

c). Penilaian Tertulis

Dalam melakukan penilaian tertulis, seorang guru juga dapat memberikan soal tes kepada siswa. Sebagaimana yang diungkapkan oleh Nurgiyantoro (2001) bahwa cara menilai kemampuan menulis adalah melalui jalan tes. Namun, Ia juga menegaskan bahwa penilaian yang dilakukan terhadap karangan siswa biasanya bersifat holistik, impresif, dan selintas; yaitu penilaian yang bersifat menyeluruh berdasarkan kesan yang diperoleh dari membaca karangan siswa secara selintas.

d). Penilaian Tes Lisan

Tes bentuk lisan merupakan tes yang dilakukan dengan bertanya langsung kepada peserta didik. Kunandar (2014) menyatakan bahwa 
penilaian lisan adalah tes yang dipergunakan untuk mengukur tingkat pencapaian kompetensi, terutama pengetahuan (Kognitif) di mana guru memberikan pertanyaan langsung kepada peserta didik secara verbal (bahasa lisan) dan ditanggapi oleh peserta didik secara langsung dengan menggunakan bahasa verbal (lisan) juga. Tes lisan bisa digunakan pada saat ulangan harian, ulangan tengah semester, ulangan akhir semester, ujian tingkat kompetensi, ujian mutu tingkat kompetensi, dan ujian sekolah.

e). Penilaian Penugasan

Penilaian penugasan merupakan penilaian yang diberikan kepada siswa ketika ada beberapa tugas yang harus diselesaikannya. Penilaian penugasan dapat berupa pekerjaan rumah atau proyek yang dikerjakan secara individu maupun kelompok sesuai dengan karakteristik tugas yang diberikan. Kunandar (2014) menyatakan bahwa penilaian penugasan bertujuan untuk pendalaman terhadap penguasaan kompetensi pengetahuan yang telah dipelajari atau dikuasai di kelas melalui proses pembelajaran. Sehingga dengan adanya penugasan ini diharapkan kepada peserta didik agar lebih mudah menyerap materi pembelajaran yang diberikan.

\section{Pengertian Sastra dan Jenisnya}

Sastra (Sanskerta: shastra) merupakan kata serapan dari bahasa Sanskerta 'Sastra', yang berarti “teks yang mengandung instruksi" atau "pedoman", dari kata dasar 'Sas' yang berarti "instruksi" atau "ajaran" dan 'Tra' yang berarti "alat" atau "sarana". Dalam bahasa Indonesia kata ini biasa digunakan untuk merujuk kepada "kesusastraan" atau sebuah jenis tulisan yang memiliki arti atau keindahan tertentu. Segmentasi sastra lebih mengacu sesuai defenisinya sebagai sekedar teks. Sedang sastrawi lebih mengarah pada sastra yang kental 
nuansa puitis atau abstraknya. Istilah sastrawan adalah salah satu contohnya, diartikan sebagai orang yang menggeluti sastrawi.

Dalam penelitian ini jenis sastra yang diambil adalah puisi. Berikut penjelasannya:

a) Pembelajaran Puisi

Puisi adalah bentuk karya sastra yang paling tua. Menurut Mulyana yang dikutip oleh Waluyo (1995) puisi merupakan bentuk kesusastraan yang menggunakan pengulangan suara sebagai ciri khasnya. Menurut Herbert Spencer yang dikutip oleh Waluyo (1995) puisi merupakan bentuk pengucapan gagasan yang bersifat emosional dengan mempertimbangkan efek keindahan. Dengan puisi, siswa dapat meluapkan perasaannya secara spontan dengan penuh gaya dan ekspresi.

\section{Pendidikan Karakter dan Nilai - Nilainya}

Pendidikan karakter merupakan sebuah istilah yang semakin hari semakin mendapatkan pengakuan dari masyarakat Indonesia saat ini. Menurut Megawangi (2004), pendidikan karakter adalah sebuah usaha untuk mendidik anak-anak agar dapat mengambil keputusan dengan bijak dan mempraktekkannya dalam kehidupan sehari-hari, sehingga m9ereka dapat memberikan kontribusi yang positif kepada lingkungannya.

Lebih lanjut, Gaffar (2010) menjelaskan bahwa pendidikan karakter adalah sebuah proses transformasi nilai-nilai kehidupan untuk ditumbuhkembangkan dalam kepribadian seseorang sehingga menjadi satu dalam perilaku kehidupan orang itu. 
Pendidikan karakter dapat mempengaruhi perkembangan pribadi siswa. Buchori (2007) mengatakan bahwa pengembangan karakter membawa anak ke pengenalan nilai secara kognitif, penghayatan nilai secara afektif, akhirnya ke pengamalan nilai secara nyata.

Selain itu, karakter dapat membentuk nilai-nilai moral yang bagus sesuai dengan yang diharapkan. Menurut Lickona, karakter berkaitan dengan konsep moral (moral knonwing), sikap moral (moral felling), dan perilaku moral (moral behavior). Berdasarkan ketiga komponen ini dapat dinyatakan bahwa karakter yang baik didukung oleh pengetahuan tentang kebaikan, keinginan untuk berbuat baik, dan melakukan perbuatan kebaikan.

Adapun nilai nilai pendidikan karakter untuk pendidikan budaya dan karakter bangsa, yaitu: Religius, jujur, toleransi, disiplin, kerja keras, kreatif, mandiri, demokratis, rasa ingin tahu, semangat kebangsaan, cinta tanah air, menghargai prestasi, bersahabat/komunikatif, cinta damai, senang membaca, peduli sosial, peduli lingkungan, dan tanggung.

\section{METODE PENELITIAN}

Metode penelitian ini menggunakan metode penelitian kombinasi (Mixed Methods) dan desain penelitian ini menggunakan Sequential Explanatory. Menurut Sugiyono bahwa, Model penelitian Sequential Explonatory design dicirikan dengan melakukan pengumpulan data dan analisis data kuantitatif pada tahap pertama, dan diikuti dengan pengumpulan dan analisis data kualitatif pada tahap kedua, guna memperkuat hasil penelitian kuantitatif yang dilakukan pada tahap pertama. (Sugiyono, 2011: 409). Adapun lokasi penelitian ini dilaksanakan di MIN 2 Aceh Tamiang tepatnya di Jalan Medan - Banda Aceh, Simpang IV Upah Kecamatan Karang Baru Kabupaten Aceh 
Tamiang. MIN 2 Aceh Tamiang. Sementara waktu penelitian dilaksanakan pada 1 - 10 Agustus 2018 dan pada saat jam pembelajaran berlangsung. Adapun tekhnik pengumpulan data dalam penelitian ini adalah observasi dan dokumentasi.

\section{TEMUAN DAN PEMBAHASAN}

\section{Pelaksanaan Penilaian Autentik Pada Pembelajaran Puisi Berbasis Pendidikan Karakter}

Hasil penelitian yang dilakukan di MIN 2 Aceh Tamiang menunjukkan bahwa penilaian autentik pada pembelajaran sastra dengan kompetensi dasar mengungkapkan pikiran, perasaan dan informasi secara tertulis dalam bentuk paragraf dan puisi dilakukan langkahlangkah pembelajaran, yaitu: (a) membaca puisi dengan gaya, mimik, dan intonasi yang tepat; dan (b) menulis puisi.

Penilaian autentik yang diterapkan dalam materi tersebut adalah penilaian kinerja, observasi (pengamatan), dan tes tulis.

\section{a. Penilaian dalam Mendemonstrasikan Puisi}

Adapun untuk menilai hasil mendemontrasikan puisi, penilaian yang dilakukan adalah penilaian kinerja dan observasi. Berikut penjelasan dari penilaian.

1). Penilaian Kinerja

Berdasarkan hasil penelitian yang peneliti lakukan pada tanggal 06 - 07 Agustus 2018 telah diketahui bahwa dalam menilai pembelajaran sastra khususnya puisi, maka penilaian yang dilakukan adalah penilaian kinerja. Hasil dari penilaian kinerja menunjukkan bahwa nilai yang diperoleh siswa sudah mencapai KKM. Hal ini 
terlihat dari rincian pada penilaian kinerja yang dipaparkan sebagai berikut:

a. Pada indikator ketepatan bacaan puisi, nilai tertinggi siswa mencapai 90 dengan persentase 20\% yang diperoleh oleh 6 siswa. Sedangkan nilai terendah siswa juga mencapai $20 \%$ dengan nilai 60.

b. Pada indikator gaya (gesture) terlihat masih banyak siswa yang belum mampu mengekspresikan gaya. Dari 30 siswa (100\%) hanya 1 siswa (3\%) yang mampu mendemosntrasikan puisi dengan gaya yang bagus dengan nilai 90. Sedangkan 57\% (17 siswa) mencapai nilai terendah yaitu 55.

c. Pada indikator mimik, terlihat ada 4 siswa yang dapat mencapai nilai tertinggi yaitu 90 dengan persentase (13\%). Hal ini ditunjukkan pada siswa ketika membaca puisi, ia menunjukkan mimik yang sesuai dengan isi puisi. Sementara nilai terendah siswa mencapai 37\% dengan nilai 60 yang diperoleh 11 siswa.

d. Untuk indikator intonasi, nilai tertinggi siswa mencapai 90 dengan persentase $10 \%$ yang dicapai oleh 3 siswa. Sedangkan nilai terendah mencapai 43\% dengan nilai 60 yang terdiri dari 13 siswa. Sedangkan 14 siswa lainnya rata-rata mendapat nilai 70 dan 80 dengan persentase $47 \%$.

e. Pada indikator pelafalan, nilai tertinggi mencapai 90 yang diperoleh 2 siswa dengan persentase $7 \%$. Sedangkan nilai terendah mencapai 10\% yang diperoleh 1 siswa dengan nilai 55 . Nilai rata-rata siswa mencapai 80 yang diperoleh 27 siswa dengan persentase $90 \%$. 


\section{b. Hasil Uji Normalitas}

\section{Ketepatan Bacaan Puisi}

Tests of Normality

\begin{tabular}{|c|c|c|c|c|c|c|}
\hline & \multicolumn{3}{|c|}{ Kolmogorov-Smirnov $^{a}$} & \multicolumn{3}{|c|}{ Shapiro-Wilk } \\
\hline & Statistic & $\mathrm{df}$ & Sig. & Statistic & Df & Sig. \\
\hline $\begin{array}{l}\text { Ketepatan Baca } \\
\text { Puisi }\end{array}$ & ,147 & 30 & ,095 & ,894 & 30 & ,006 \\
\hline
\end{tabular}

a. Lilliefors Significance Correction

Dari hasil uji normalitas di atas terlihat bahwa Ketepatan Baca Puisi memiliki P-value $=0,095$ untuk uji Normalitas Liliefors (Kolmogrov Smirnov) dan P-value $=0,006$ untuk uji normalitas Shapiro - Wilk. Salah satu P-value kurang dari $\propto=0.05$. sehingga data tidak berdistribusi normal. Karena tidak berdistribus normal tidak dapat dilanjutkan analisis menggunakan uji - t satu sampel.Uji selanjutnya yang dilakukan uji non parametrik yaitu uji binomial.

\section{a. Gaya}

Tests of Normality

\begin{tabular}{|l|r|r|r|r|r|r|}
\hline \multirow{2}{*}{} & \multicolumn{3}{|c|}{ Kolmogorov-Smirnov $^{\mathrm{a}}$} & \multicolumn{3}{c|}{ Shapiro-Wilk } \\
\cline { 2 - 7 } & Statistic & Df & \multicolumn{1}{c|}{ Sig. } & Statistic & Df & \multicolumn{1}{c|}{ Sig. } \\
\hline Gaya &, 299 & 30 &, 000 &, 594 & 30 &, 000 \\
\hline
\end{tabular}

a. Lilliefors Significance Correction

Dari hasil uji normalitas di atas terlihat bahwa Gaya memiliki P-value $=0,000$ untuk uji Normalitas Liliefors (Kolmogrov Smirnov) dan P-value $=$ 0,000 untuk uji normalitas Shapiro - Wilk. Salah satu P-value kurang dari $\propto=0.05$. sehingga data tidak berdistribusi normal. Karena tidak berdistribus normal tidak dapat dilanjutkan analisis menggunakan uji - t satu sampel.Uji selanjutnya yang dilakukan uji non parametrik yaitu uji binomial. 


\section{b. Mimik}

\section{Tests of Normality}

\begin{tabular}{|r|r|r|r|r|r|r|}
\hline \multirow{2}{*}{} & \multicolumn{3}{|c|}{ Kolmogorov-Smirnov $^{\mathrm{a}}$} & \multicolumn{3}{c|}{ Shapiro-Wilk } \\
\cline { 2 - 8 } & Statistic & Df & \multicolumn{1}{c|}{ Sig. } & Statistic & \multicolumn{1}{c|}{ Df } & \multicolumn{1}{c|}{ Sig. } \\
\hline Mimik &, 325 & 30 &, 000 &, 736 & 30 &, 000 \\
\hline
\end{tabular}

a. Lilliefors Significance Correction

Dari hasil uji normalitas di atas terlihat bahwa mimik memiliki Pvalue $=0,000$ untuk uji Normalitas Liliefors (Kolmogrov Smirnov) dan Pvalue $=0,000$ untuk uji normalitas Shapiro - Wilk. Salah satu P-value kurang dari $\propto=0.05$. sehingga data tidak berdistribusi normal. Karena tidak berdistribus normal tidak dapat dilanjutkan analisis menggunakan uji - t satu sampel.Uji selanjutnya yang dilakukan uji non parametrik yaitu uji binomial.

\section{c. Intonasi}

Tests of Normality

\begin{tabular}{|l|r|r|r|r|r|c|}
\hline \multirow{2}{*}{} & \multicolumn{3}{|c|}{ Kolmogorov-Smirnov $^{\mathrm{a}}$} & \multicolumn{3}{c|}{ Shapiro-Wilk } \\
\cline { 2 - 7 } & Statistic & Df & \multicolumn{1}{c|}{ Sig. } & Statistic & Df & \multicolumn{1}{c|}{ Sig. } \\
\hline Intonasi &, 406 & 30 &, 000 &, 601 & 30 &, 000 \\
\hline
\end{tabular}

a. Lilliefors Significance Correction

Dari hasil uji normalitas di atas terlihat bahwa intonasi memiliki P-value = 0,000 untuk uji Normalitas Liliefors (Kolmogrov Smirnov) dan P-value $=$ 0,000 untuk uji normalitas Shapiro - Wilk. Salah satu P-value kurang dari $\propto=0.05$. sehingga data tidak berdistribusi normal. Karena tidak berdistribus normal tidak dapat dilanjutkan analisis menggunakan uji - t satu sampel.Uji selanjutnya yang dilakukan uji non parametrik yaitu uji binomial.

\section{d. Pelafalan}

\section{Tests of Normality}




\begin{tabular}{|c|r|r|r|r|r|c|}
\hline \multirow{2}{*}{} & \multicolumn{3}{|c|}{ Kolmogorov-Smirnov $^{\mathrm{a}}$} & \multicolumn{3}{c|}{ Shapiro-Wilk } \\
\cline { 2 - 7 } & Statistic & Df & \multicolumn{1}{c|}{ Sig. } & Statistic & df & \multicolumn{1}{c|}{ Sig. } \\
\hline Pelafalan &, 246 & 30 &, 000 &, 805 & 30 &, 000 \\
\hline
\end{tabular}

a. Lilliefors Significance Correction

Dari hasil uji normalitas di atas terlihat bahwa pelafalan memiliki P-value $=$ 0,000 untuk uji Normalitas Liliefors (Kolmogrov Smirnov) dan P- value $=$ 0,000 untuk uji normalitas Shapiro - Wilk. Salah satu P-value kurang dari $\propto=0.05$. sehingga data tidak berdistribusi normal. Karena tidak berdistribus normal tidak dapat dilanjutkan analisis menggunakan uji - $\mathrm{t}$ satu sampel.Uji selanjutnya yang dilakukan uji non parametrik yaitu uji binomial.

\section{c. Pembentukan Karakter Siswa dalam Mendemonstrasikan Puisi}

Pada saat mendemonstrasikan puisi, pembentukan karakter utama yang diharapkan muncul dalam proses pembelajaran ini adalah adalah karakter disiplin, semangat, bersahabat, dan tanggung jawab.

1. Pada karakter disiplin, didapatkan hasil dari 30 siswa, terdapat 13 siswa $(43 \%)$ yang mencapai skala 5 dengan kriteria selalu konsisten. Dalam mendemonstrasikan puisi, siswa diminta guru untuk membaca puisi di depan kelas dan siswa mematuhinya. Sedangkan 8 siswa lainnya (27\%) telah mulai konsisten dalam mematuhi perintah yang diberikan.

2. Pada karakter semangat, terdapat 20 siswa yang selalu konsisten dengan persentase 67\%. Untuk 6 siswa, semangatnya telah konsisten dengan persentase $20 \%$ dan untuk 4 siswa lainnya sudah mulai konsisten dalam membaca puisi dengan jiwa semangatnya. 
3. Sedangkan karakter tanggung jawab, terdapat 22 siswa yang mampu mencapai skala 5 dengan persentase $73 \%$. Adapun skala terendah hanya dicapai oleh 2 siswa dengan skala 3. Hal ini dikarenakan siswa tersebut kurang bertanggung jawab dalam mendemonstrasikan puisinya. Ketika ditanya oleh guru, siswa mengaku merasa malu untuk tampil ke depan. Selebihnya siswa telah mencapai skala 4 dengan persentase 13\%. (lampiran 2)

\section{d. Penilaian untuk Menulis Puisi}

1. Penilaian Kinerja

Berdasarkan hasil penelitian telah diketahui bahwa pada indikator sesuai dengan tema, semua siswa telah menulis puisi sesuai dengan tema yang diberikan yaitu tema "bersahabatlah". Tidak ada satupun siswa yang menulis judul lain. Terlihat dari 30 siswa (100\%), semuanya menulis judul dengan baik sesuai dengan tema yang telah diberikan. Hal ini menunjukkan bahwa siswa memang benar-benar memahami petunjuk yang telah diberikan oleh guru.

Pada indikator terdapat bahasa kiasan, dalam puisi ini tidak memiliki bahasa kiasan. Hal ini disebabkan karena puisi tersebut ditujukan untuk siswa SD/MI yang masih menggunakan bahasa yang sederhana. Terlihat dari 30 siswa $(100 \%)$, mereka menulis puisi yang sangat mudah dipahami.

Pada indikator terdapat amanat, di dalam puisi "bersahabatlah" yang telah dibuat oleh siswa telah mengandung amanat. Hal ini terlihat dari isi puisi yang telah ditulisnya. Terlihat dari 30 siswa semuanya menuliskan puisi dengan berbagai amanat yang terkandung di dalamnya. 
Pada indikator jumlah baris yang ditulis oleh siswa, terdapat 8 siswa yang menulis tanpa memperhatikan barisnya dengan persentase $27 \%$. Hal ini diketahui dari puisi yang ditulisnya mirip seperti bentuk cerita. Ini disebabkan karena siswa kurang teliti dan kurang memahami tentang jumlah baris dalam puisi. Sementara 22 siswa lainnya telah menulis puisi sesuai dengan jumlah baris yang umumnya terdapat dalam puisi dengan persentase $73 \%$.

Pada indikator menggunakan kata-kata kunci, untuk puisi ini tidak menggunakan kata-kata kunci dikarenakan puisi tersebut bahasanya masih mudah dicerna oleh siswa sehingga tidak perlu adanya kata-kata kunci. Hal ini diketahui dari isi puisi tersebut. Terlihat dari 30 siswa (100\%) semuanya tidak menggunakan kata-kata kunci. Ini menunjukkan bahwa siswa memahami tentang ketidak adaan kata-kata kunci dalam puisi yang mereka tulis.

\section{e. Pembentukan Karakter Siswa dalam Menulis Puisi}

Adapun karakter yang ingin dimunculkan pada setiap siswa dalam menulis puisi adalah karakter jujur, kerja keras, mandiri, semangat, dan tanggung jawab.

1) Pada karakter jujur, terlihat dari 30 siswa hanya ada 3 siswa yang mendapat skala 3 yaitu dengan kriteria mulai konsisten.

2) Pada karakter kerja keras, terdapat 22 anak (73\%) yang sudah selalu konsisten dalam menulis. Hal ini ditunjukkan ketika siswa menulis puisi, mereka sangat antusias dalam mengerjakan semua yang diperintahkan oleh guru, siswa juga tidak mengeluh capek, 
dan selesai pada waktu yang ditentukan. Sedangkan 5 anak lainnya $(17 \%)$ sudah mulai nampak ke konsistenannya.

3) Karakter mandiri telah banyak yang selalu konsisten juga ditunjukkan oleh 14 siswa dari 30 siswa.

4) Karakter semangat muncul ketika siswa diminta untuk menuliskan puisi, mereka langsung membuka buku dan mengerjakan perintah dari gurunya. Dilihat dari 30 siswa, ada sebanyak 20 siswa yang semangatnya begitu luar biasa. Selebihnya siswa sudah mulai konsisten dalam memupuk jiwa semangatnya.

5) Adapun karakter tanggung jawab telah ditunjukkan oleh siswa yang tidak berhenti menulis sebelum selesai dan mereka selalu menyelesaikan tulisannya dengan baik dan benar. Hal ini juga ditunjukkan oleh 22 siswa dengan persentase 73\%. Sementara itu, beberapa siswa lainnya telah memiliki rasa tanggung jawab yang konsisten dan mulai konsisten. (lampiran 4)

\section{B. Uji Binomial}

\section{Keterampilan Membaca Puisi}

\section{Binomial Test}

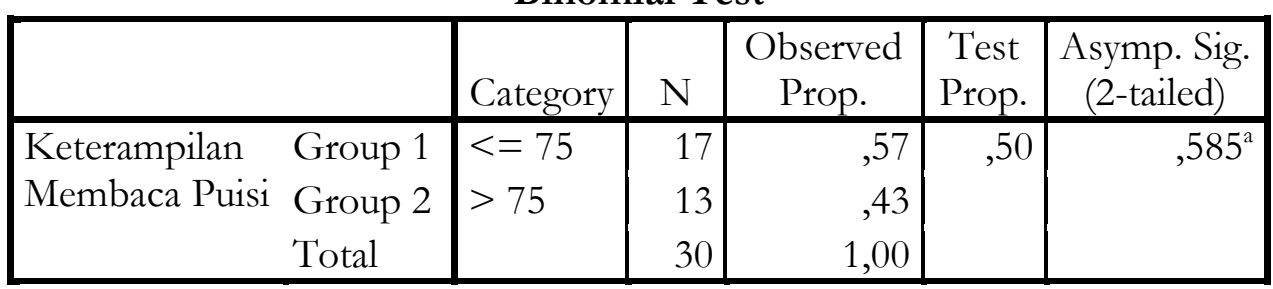

a. Based on Z Approximation. 
Dari Jumlah responden sebanyak 30 orang siswa, siswa yang memiliki nilai kurang atau sama dengan KKM (75) sebanyak 17 orang dengang persentase sebesar $67 \%$ dan siswa yang memiliki nilai lebih dari KKM 13 orang dengan persentase $43 \%$.

Dari tabel diatas diperoleh Nilai Sig (2-tailed) sebesar 0,585 lebih dari 0.05. Sehingga $\mathrm{H}_{0}$ diterima dan $\mathrm{H}_{a}$ ditolak. Maka lebihdapat disimpulkan bahwa nilai rata - rata keterampilan membaca puisi siswa sama dengan KKM.

\section{a. Gaya/ Gestur}

\section{Binomial Test}

\begin{tabular}{|ll|l|r|r|r|c|}
\hline & Category & $\mathrm{N}$ & \multicolumn{1}{|c|}{$\begin{array}{c}\text { Observed } \\
\text { Prop. }\end{array}$} & Test Prop. & $\begin{array}{c}\text { Asymp. Sig. } \\
\text { (2-tailed) }\end{array}$ \\
\hline Gaya & Group 1 & $<=75$ & 29 &, 97 &, 50 &, $000^{2}$ \\
& Group 2 & $>75$ & 1 &, 03 & & \\
& Total & & 30 & 1,00 & & \\
\hline
\end{tabular}

a. Based on Z Approximation.

Dari Jumlah responden sebanyak 30 orang siswa, siswa yang memiliki nilai kurang atau sama dengan KKM (75) sebanyak 29 orang dengang persentase sebesar $97 \%$ dan siswa yang memiliki nilai lebih dari KKM 1 orang dengan persentase $3 \%$.

Dari tabel diatas diperoleh Nilai Sig (2-tailed) sebesar 0,00 kurang dari 0.05.

Sehingga $\mathrm{H}_{0}$ ditolak dan $\mathrm{H}_{a}$ diterima. Maka dapat disimpulkan nilai rata - rata kemampuan gaya siswa tidak sama dengan KKM.

\section{b. . Mimik}

\section{Binomial Test}

\begin{tabular}{|c|l|r|r|r|r|}
\hline & Category & $\mathrm{N}$ & \multicolumn{1}{c|}{$\begin{array}{c}\text { Observed } \\
\text { Prop. }\end{array}$} & Test Prop. & $\begin{array}{c}\text { Asymp. Sig. } \\
\text { (2-tailed) }\end{array}$ \\
\hline Mimik Group 1 & $<=75$ & 26 &, 87 &, 50 &, $000^{2}$ \\
Group 2 & $>75$ & 4 &, 13 & & \\
Total & & 30 & 1,00 & & \\
\hline
\end{tabular}


Binomial Test

\begin{tabular}{|r|l|r|r|r|r|}
\hline & Category & $\mathrm{N}$ & \multicolumn{1}{|c|}{$\begin{array}{c}\text { Observed } \\
\text { Prop. }\end{array}$} & Test Prop. & $\begin{array}{c}\text { Asymp. Sig. } \\
\text { (2-tailed) }\end{array}$ \\
\hline Mimik Group 1 & $<=75$ & 26 &, 87 &, 50 &, $000^{2}$ \\
Group 2 & $>75$ & 4 &, 13 & & \\
Total & & 30 & 1,00 & & \\
\hline
\end{tabular}

a. Based on Z Approximation.

Dari Jumlah responden sebanyak 30 orang siswa, siswa yang memiliki nilai kurang atau sama dengan KKM (75) sebanyak 26 orang dengang persentase sebesar $87 \%$ dan siswa yang memiliki nilai lebih dari KKM 4 orang dengan persentase $13 \%$.

Dari tabel diatas diperoleh Nilai Sig (2-tailed) sebesar 0,00 kurang dari 0.05.

Sehingga $\mathrm{H}_{0}$ ditolak dan $\mathrm{H}_{\mathrm{a}}$ diterima. Maka dapat disimpulkan nilai rata - rata kemampuan mimik siswa tidak sama dengan 75

\section{c. Intonasi}

\section{Binomial Test}

\begin{tabular}{|c|c|c|c|c|c|c|}
\hline & & Category & $\mathrm{N}$ & $\begin{array}{l}\text { Observed } \\
\text { Prop. }\end{array}$ & Test Prop. & $\begin{array}{l}\text { Asymp. Sig. } \\
\text { (2-tailed) }\end{array}$ \\
\hline Intonasi & $\begin{array}{l}\text { Group } 1 \\
\text { Group } 2 \\
\text { Total }\end{array}$ & $\begin{array}{l}<=75 \\
>75\end{array}$ & $\begin{array}{r}27 \\
3 \\
30\end{array}$ & $\begin{array}{r}, 90 \\
, 10 \\
1,00\end{array}$ &, 50 &, $000^{\mathrm{a}}$ \\
\hline
\end{tabular}

a. Based on Z Approximation.

Dari Jumlah responden sebanyak 30 orang siswa, siswa yang memiliki nilai kurang atau sama dengan KKM (75) sebanyak 27 orang dengang persentase sebesar $90 \%$ dan siswa yang memiliki nilai lebih dari KKM 3 orang dengan persentase $10 \%$.

Dari tabel diatas diperoleh Nilai Sig (2-tailed) sebesar 0,00 kurang dari 0.05. Sehingga $\mathrm{H}_{0}$ ditolak dan $\mathrm{H}_{\mathrm{a}}$ diterima. Maka dapat disimpulkan nilai rata - rata kemampuan intonasi siswa tidak sama dengan 75 


\section{d. Pelafalan}

\section{Binomial Test}

\begin{tabular}{|rl|l|r|r|r|c|}
\hline & & Category & \multicolumn{1}{|c|}{$\mathrm{N}$} & $\begin{array}{c}\text { Observe } \\
\text { d Prop. }\end{array}$ & $\begin{array}{c}\text { Test } \\
\text { Prop. }\end{array}$ & $\begin{array}{c}\text { Asymp. Sig. } \\
\text { (2-tailed) }\end{array}$ \\
\hline Pelafalan & Group 1 & $<=75$ & 24 &, 80 &, 50 &, $001^{2}$ \\
& Group 2 & $>75$ & 6 &, 20 & & \\
& Total & & 30 & 1,00 & & \\
\hline
\end{tabular}

a. Based on Z Approximation.

Dari Jumlah responden sebanyak 30 orang siswa, siswa yang memiliki nilai kurang atau sama dengan KKM (75) sebanyak 24 orang dengang persentase sebesar $80 \%$ dan siswa yang memiliki nilai lebih dari KKM 6 orang dengan persentase $20 \%$.

Dari tabel diatas diperoleh Nilai Sig (2-tailed) sebesar 0,001 kurang dari 0.05. Sehingga $\mathrm{H}_{0}$ ditolak dan $\mathrm{H}_{2}$ diterima. Maka dapat disimpulkan nilai rata - rata kemampuan pelafalan siswa tidak sama dengan 75

\section{KESIMPULAN}

Berdasarkan hasil penelitian dan penemuan yang dilakukan di MIN 2 Aceh Tamiang, penelitian ini dapat disimpulkan bahwa penilaian autentik berbasis pendidikan karakter mudah diterapkan dalam pembelajaran sastra khususnya pada materi puisi.

Hasil penelitian menunjukkan bahwa penilaian pada pembelajaran puisi mencakup penilaian kinerja, observasi (pengamatan), dan tes tulis. Sedangkan penilaian pada dongeng mencakup penilaian kinerja, penilaian lisan, dan penugasan. Dalam hal ini penilaian dilakukan pada saat pembelajaran berlangsung dan dilakukan secara menyeluruh. Hal ini juga menunjukkan bahwa penilaian autentik tidak hanya cocok dilaksanakan 
dalam pembelajaran tertentu saja, bahkan sangat cocok diterapkan pada pembelajaran sastra.

Pada pembelajaran puisi, indikator yang dinilai adalah pada indicator mendemonstrasikan dan menulis puisi. Pada indicator mendemonstrasikan puisi, nilai yang diperoleh siswa sudah memuaskan. Penilaian yang dilakukan adalah penilaian kinerja. Sedangkan pada indikator menulis puisi, penilaian yang dilakukan juga penilaian kinerja. Hal ini dilakukan dengan tujuan agar tugas yang dikerjakan siswa menjadi lebih bermakna dan memudahkan siswa untuk memahami materi pembelajaran. Dan hasil yang didapatkan benar-benar sangat berpengaruh. Perkembangan anak menjadi lebih baik dan lebih antusias dalam belajar.

Selain itu, peneliti juga memperoleh temuan mengenai karakter yang muncul dari setiap siswa. Adapun karakter yang muncul pada pembelajaran puisi mencakup karakter disiplin, semangat, tanggung jawab, jujur, kerja keras, dan mandiri. Dari berbagai karakter yang muncul tersebut telah menunjukkan bahwa pembelajaran sastra mampu menumbuh kembangkan karakter anak menjadi lebih baik dan terarah. Sehingga dalam pembelajaran sastra anak akan lebih aktif, kreatif, dan produktif.

\section{DAFTAR PUSTAKA}

Majid, A., \& Aziz, A. (2002). Mendidik dengan cerita. Bandung: PT Remaja Rosdakarya.

Abidin, Y. (2013). Pembelajaran bahasa berbasis pendidikan karakter. Bandung: PT Refika Aditama. 
Andrade, F.G., Sanchez, D., Penacino, G., \&Jarreta, B.M. (2009). Two fathers for the same child: A deficient paternity case of false inclusion with autosomic STRs. Forensic Science International: Genetics 3.

Ardini, P. P. (2012). Pengaruh dongeng dan komunikasi terhadap perkembangan moral anak usia 7-8 tahun. Jurnal Pendidikan PAUD Universitas Negeri Gorontalo, 1(1).

Arikunto, S. (1993). Manajemen penelitian. Jakarta: PT Rineka Cipta.

Atmazaki.(2013). Penilaian Alternatif dalam pembelajaran bahasa Indonesia. Padang: UNP Press.

Brown, H. D. (2004). Language assessment: Principles and classroom practices. New York: Longman.

Buchori, M. (2007). Evaluasi pendidikan di Indonesia, dari Kweekshool sampai ke IKIP:1815-1998. Yogyakarta:Insist Press.

Nurgiyantoro, B. (2001). Penilaian dalan pengajaran bahasa dan sastra. Yogyakarta: BPFE.

Departemen Pendidikan dan Kebudayaan RI. Kamus Besar Bahasa Indonesia. Cet. 262.

Effendi, S. (2004). Bimbingan apresiasi puisi. Jakarta: Pustaka Jaya.

F.L, Whitney. (1960). The elements of resert Asian Eds. Osaka: Overseas Book Co.

Gaffar, M. F. (2010, April). Pendidikan karakter berbasis Islam. Workshop Pendidikan Karakter Berbasis Agama, Yogyakarta.

Herfanda, A.Y. (2008). Sastra sebagai agen perubahan budaya dalam bahasa dan budaya dalam berbagai perspektif. Yogyakarta: FBS UNY dan Tiara Wacana.

Kesuma, D., dkk. (2011). Pendidikan karakter. Bandung: Remaja Rosdakarya.

Kunandar. (2014). Penilaian autentike Penilaian basil belajar peserta didik berdasarkan Kurikulum 2013): Suatu pendekatan praktis disertai dengan contoh (Ed. rev.). Jakarta: Rajawali Pers.

Megawangi, R. (2004). Pendidikan karakter: Solusi yang tepat untuk membangun bangsa. Bogor: Indonesia Heritage Foundation.

Nazir, M. (1988). Metode penelitian. Jakarta: Ghalia Indonesia.

Papalia, D. E.et.all. (2008). Human development. Jakarta : Kencana Prenada Media Group. 
Priyono, K. (2006). Terampil mendongeng. Jakarta : Grasindo.

Sugiyono. (2010). Memahami penelitian kuantitatif, kualitatif dan $R \& D$. Bandung: Alfabeta.

Waluyo, H. J. (1995). Teori dan apresiasi puisi. Jakarta: Gelora Aksara Pratama. 